\title{
A Case Study of Fisheries Governance and Management in a Reservoir of Lao PDR: Perspectives for Improvement
}

\author{
Eric Baran ${ }^{1}$, Theodorus Visser ${ }^{2}$, Maud Cottet ${ }^{2}$, Anne Tessier ${ }^{3,4}$, Eric Guerin ${ }^{5}$ and Jean Guillard ${ }^{3 *}$ \\ ${ }^{1}$ Greater Mekong Regional office, WorldFish Center, Khan Chamkar Morn, Phnom Penh, Cambodia \\ ${ }^{2}$ Nam Theun 2 Power Company Limited (NTPC), Environment \& Social Division, Environment Department Xaysettha district, Vientiane Lao PDR \\ ${ }^{3}$ Univ. Savoie Mont Blanc, INRAE, CARRTEL, 75 bis avenue de Corzent, CS 50511, 74203 Thonon-les-Bains, France \\ ${ }^{4}$ MAREPOLIS, 68 avenue des Corbière, Portel-des-Corbières, France \\ ${ }^{5}$ Siem Reap, Phnom Penh, Cambodia
}

${ }^{*}$ Corresponding author: Dr. Jean Guillard, Univ. Savoie Mont Blanc, INRAE, CARRTEL, 75 bis avenue de Corzent, CS 50511, 74203 Thonon-les-Bains, France; Email: jean.guillard@inrae.fr

Received: August 26, 2021; Accepted: September 03, 2021; Published: September 15, 2021

\begin{abstract}
Starting from a framework defining a fishery as a combination of environmental, biological, social, economic and policy components, we review the development process and current status of the reservoir fishery of Nam Theun 2 Dam in Lao PDR. The aquatic environment was extensively studied and fishing monitored; the reservoir features a low productivity. Regulation remains weak and social studies focused mainly on socioeconomic aspects, without documenting aspirations or constraints of the fishing community nor detailing fish consumption. Fish prices were monitored, but non-official trades, demands and competitions remain to be assessed. Facilitation and restrictions are documented but the trade policy framework is not, nor the consequences of regulatory measures. We last identify the degrees of control of managers over the fishery system and its components. This analysis highlights the need to apprehend a controlled reservoir fishery as a combination of aquatic habitat, fish, fishers and their economic and policy environment.
\end{abstract}

Keywords: Lake; Asia; Fish resource; Management, Tropical

\section{Introduction}

Given the increasing demand for electricity, hydropower is promoted to power supply in many developing countries [1]. In the Mekong basin in particular, massive hydropower development has occurred during the past two decades, at risk of compromising native fishery resources [2]. However, dam development also results in the creation of reservoirs, providing new habitats for fishery development in Africa [3,4] India [5], South America [6] and Asia [7]. In Asia, Lao People's Democratic Republic (PDR) has a good case study with 32 hydropower reservoirs operational, 31 under construction and 56 planned [8]. In this country, $40 \%$ of the fish production originates from reservoirs [9].

Among Laos' existing dams, the Nam Theun 2 project (Figure 1) stands out because the development of a reservoir fishery was one of the objectives of an integrated development approach from the start [10]. We review the Nam Theun 2 case study using a simple conceptual framework of a fishery as a whole to review achievements and gaps. The framework and the case study are aimed at informing options, needs and constraints for the development of sustainable fisheries in subtropical reservoirs.
The focus is on the fishery as a whole, i.e. the combination of fish, environment, fishers, and economic and policy context [11,12]. The need to integrate customer demand and marketing to sustainable fisheries management is highlighted in several studies, in particular in the Mekong basin [13]. Thus, we consider here fish supply, fish demand/marketing and the environment policy as the three main pillars of a sustainable fishery, knowing that several other factors such as biological productivity, algae blooms, limnological aspects, landuses in the catchment areas, fishing gears are also important [14]. Our study focuses only on a reservoir fishery, it does not include upstream or downstream fisheries. We set the stage by identifying the various components of a generic tropical reservoir fishery, and then document how much is known and has been done about each component in the case of Nam Theun 2. This highlights strengths and weaknesses in the knowledge base needed for the management of the system. Ultimately, the various degrees of control of managers over the fishery system and its components are identified.

\section{Components of a Fishery: the Conceptual Perspective}

This case study review is based on the analysis of Nam Theun 2 environment, fish resource, fishing, fishers, fish trade, and policies 


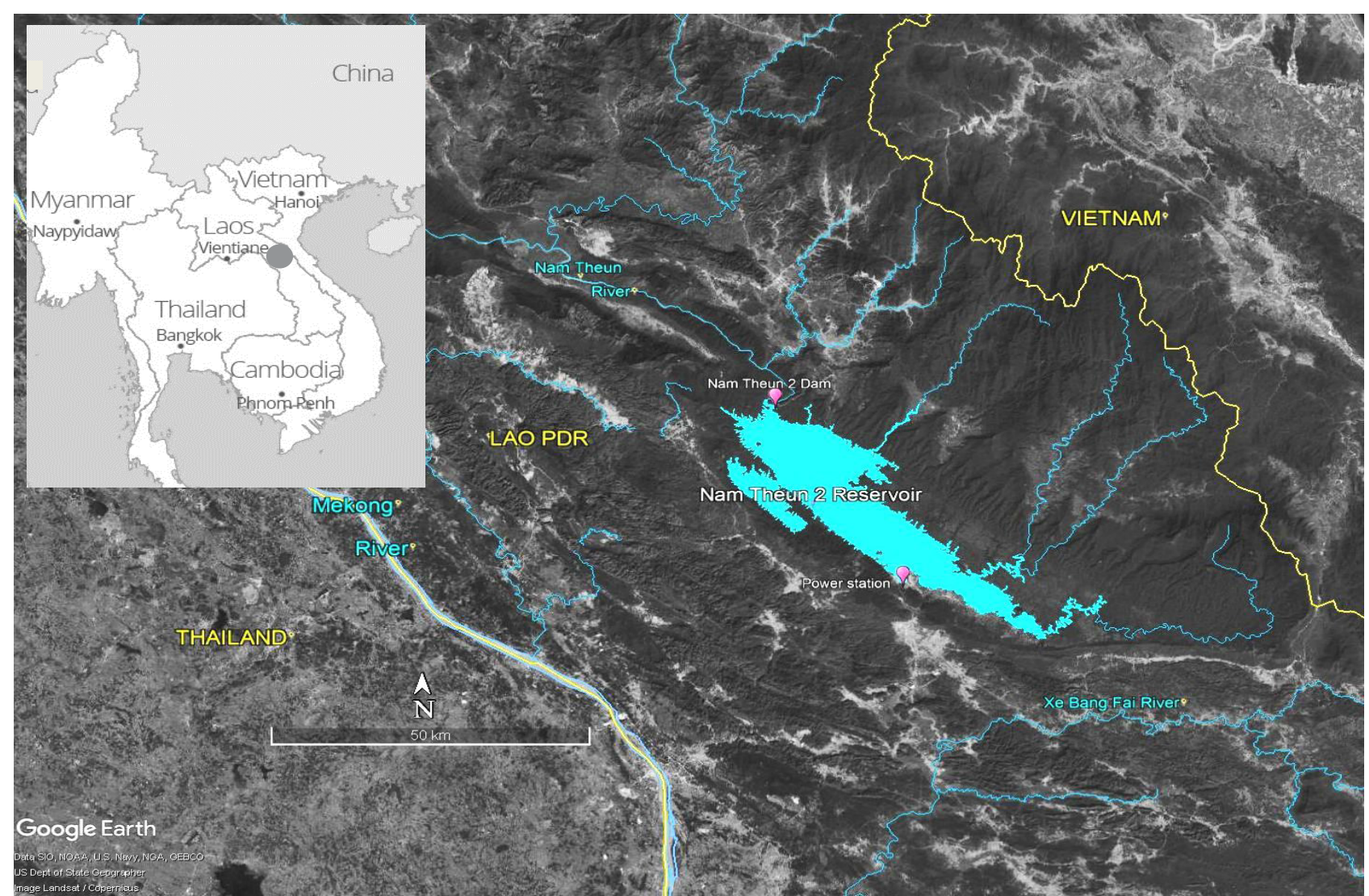

Figure 1: Location map; map data (Google Earth, Landsat).

studies, mainly from international publications and technical reports, academic theses, and presentations at conferences. They are complemented with project planning documents, reports of the panel of experts who monitored the project, project reviews, and studies of fisheries in other Lao reservoirs. In total, 167 documents were reviewed and 61, the most accessible and synthetic are referenced.

Fisheries are social-ecological systems including fish and fishers, but also economic drivers as well as beliefs and behaviors $[15,16]$. $[17,18]$ assessment frameworks serve as a basis for the present analysis (Figure 2). The fish supply, or yield, results from the interaction between fishers (number, strategies), their fishing effort and the fish stock. Put simply, the stock reflects species (local biodiversity) and their environment, the latter being a combination of water quality, limnological parameters and habitats. Similarly, the fishing effort reflects the number of boats, the number and nature of fishing gears and the intensity of activity. Fishers and their effort are influenced mainly by the level of organization, access to credit and alternatives outside the fishery sector. "Fishing effort" could be seen as a subcomponent of the "Fishers" component, but for clarity purposes, we distinguish social aspects (motivations, organizational modalities, livelihood alternatives, etc.) from purely technical aspects such as gears or boat types. With the exception of a self-consumption fraction, particularly important in the Mekong basin [19], the fish supply is entering the market.

Fish marketing consists mainly of value adding, trade, infrastructure and buyers. Value adding corresponds to transformation and quality control. Fish trade is influenced by competition (or a monopoly situation), and access of traders to credit. Infrastructure plays a key role, in particular landing sites and market places, transport options, and preservation options such as ice or smoking facilities. Last, buyers are the often neglected but ultimate drivers of the fishery, with the weight of individual preferences (for wild fish, for some particular species) and also the competition between different fish suppliers or with the aquaculture sector.

The policy environment, expressed through rules and regulations, applies to both fish supply and fish marketing; it defines and controls access rights, creates constraints (e.g., bans, taxes) or facilitates business (e.g., incentives, subsidies). The level of information about each component for the Nam Theun 2 fishery is detailed in the following sections.

\section{The Nam Theun 2 Reservoir}

The Nam Theun 2 hydropower dam is a 1070 MW trans-basin project releasing the turbined water from the Nam Theun 2 Reservoir into the Xe Bangfai River through a $27 \mathrm{~km}$ long downstream channel (Figure 1) [20]. The Nam Theun 2 reservoir impounded in 2008 is shallow ( $8 \mathrm{~m}$ depth on average) and its surface area varies between 489 $\mathrm{km}^{2}$ at full supply level to $86 \mathrm{~km}^{2}$ in the dry season. Sixteen hamlets are established along the reservoir, a part from resettlement, with a total households of more than 2,000 in 2014 and around $85 \%$ of that population is involved in fishing [21]. 




Figure 2: Components of an inland fishery as illustrated by the Nam Theun 2 reservoir fishery.

\section{Fish Supply}

Catch monitoring based on landings started in 2008 [21] and has been regularly implemented since then. The catch varied between $6.2 \mathrm{~kg} /$ household/day in 2009 just after impoundment and $2.8 \mathrm{~kg} /$ household/day in 2012-2013, with a rebound after $2013(4.3 \mathrm{~kg} /$ household/day in 2015; [22]. The annual yield varied between 1027 tons the year following the impoundment and 576 tons in the three following years, then increased again to about 1300 tons in 2016 [22]. The latter corresponds to a low productivity of $27 \mathrm{~kg}$ per hectare related to the oligo-mesotrophic status of the reservoir [21]. Currently the production results from naturally established populations and there is no institutional stocking nor aquaculture program. Overall, the fish component of the Nam Theun 2 reservoir fishery has been subject to extensive monitoring and is well documented [21,23].

\section{Fishers}

Fishers as a social group were mainly characterized through socioeconomic studies linked to resettlement $[21,24]$. In 2015, among the 2384 households around the reservoir, $71 \%$ were eligible to register as fishing households [25]. Out of these 1682 households, 27\% registered to Village Fishing Groups, and 301 households identified themselves as full-time commercial fishers [22]; only $16 \%$ of the population entitled to buying a commercial fishing license actually bought one. Despite access limited to local markets, fisheries account for about $38 \%$ of resettled communities' source of income [26], more than agriculture (20\%) that failed to become the main income component [27]. Fishing is a part-time activity whose intensity varies depending on cost-benefit considerations (in particular the price of fuel) and in relation to alternative income generating activities. Thus, although fishing is repeatedly recognized as a main source of income for villagers living by the reservoir, in particular vulnerable and poor households [28], the activity is in fact marginally profitable and constrained by external factors unrelated to the resource. For these reasons, livelihoods based on fisheries tend to be limited to a small number of households characterized by enough means and knowledge to get enough catches, while for the majority this activity only provides occasional income and a supplemental source of protein. Beyond an evaluation of community engagement in fisheries management [29], no social or anthropologic analysis detailed fishers' ambitions (e.g., preferred livelihood options in the long term, investment preferences), priority needs (e.g., subsistence vs. income, ice supply vs. transport improvement), opportunities (such as fishery organization types and modalities) or constraints (for instance access to credit) in relation to the sustainability of the activity. Multiple studies have highlighted the importance of fish in the nutrition and food security of rural populations in Laos [19]. Most resettled households in Nam Theun 2 reservoir fish, at least partly, for subsistence [22]. Nam Theun 2 Power Company [10] mentions a self-consumption of around $60 \mathrm{~kg}$ per person per year, and more recent estimates (unpublished NTPC annual fisheries reports) value fish consumption around the reservoir at $33 \mathrm{~kg}$ per person and per year. In 2016, with a population around the reservoir reaching 11,000 people, a total registered catch of 1,347 tons and $17.5 \%$ of self-consumption (12.5\% fresh and $5 \%$ processed), self-consumption could be valued at $21 \mathrm{~kg} /$ person/year.

\section{Fishing Effort}

Fishing effort was monitored from November 2008 to June 2018 and reported in NTPC's annual Fisheries Reports. Daily catches were related to boat type and their number (from 610 to 646 registered boats). Overall, the number of registered fishing boats decreases, whereas the catch went up between 2013 and 2016. One major constraint in assessing the actual fishing effort lies in the fact that i) only residents of the displaced villages are eligible for a fishing license 
and ii) only eligible fishing households are allowed to register fishing boats. Non-eligible households' fish without a license or have boats registered in the name of eligible households, and eligible households do not always register all of their boats. Thus, it is believed, based on independent assessment and samples [21], that only about four out of seven commercial fishing households are registered. This situation reflects the low intensity of law enforcement and the limited risk of being fined when fishing without a license. Fishing is also acknowledged in protected zones, with a correlation between years of higher catch and of poor enforcement in these zones [21]. Overall, regulation of fishing effort in the Nam Theun 2 reservoir has been recognized weak, with a high potential for improvement [26].

\section{Fish Surveys}

The reservoir fish stock and its dynamics have been assessed by scientific fish survey monitoring combined with hydro-acoustic surveys [23,24]. Monitoring started in 2008 prior to reservoir impoundment and used experimental gillnet surveys [30]; lengthweight relationships and life traits were also collected [31-33]. Results illustrate a typical three-phase process [34], with a trophic explosion and the proliferation of some species (2008-2009), followed by a rapid trophic depletion within a few months (2009-2010) and then a stabilization with a reduced variability and the dominance of very few species: five species make up to $94 \%$ of the total catch [30]. Two years after impoundment, the reservoir was characterized by a low annual fish production of about $20 \mathrm{~kg} / \mathrm{ha}$ [21]. This productivity is the maximum expected; ensuring fishery sustainability would mainly consist in securing such production level. Using hydro-acoustic data, the fish stock was estimated in the deepest zones of the reservoir and showed a very low fish biomass of around $1 \mathrm{~kg} / \mathrm{ha}$ [23].

\section{Fish Diversity}

Fish biodiversity studies started in 1996 during the environmental impact assessment and the discovery of several dozen new species $[35,36]$. Thus, taxonomic surveys triggered by dam construction resulted in an explosion of fish biodiversity records. Within the reservoir, [30] and [21] showed that the original riverine fish community evolved after impoundment towards a lentic pattern, the formerly dominant native high value river species being replaced by two fast-growing limnophilic low value species, an ubiquist Barb (Hampala macrolepidota) [32] and the non-indigenous opportunistic Tilapia (Oreochromis niloticus) [33].

\section{Environmental Parameters}

The environment of the reservoir has been subject to multiple studies [20], starting with a hydrodynamic and water quality model based on the monitoring of 15 parameters [37]. A 3D model allows assessing the impact of watershed management on the primary productivity of the reservoir [38,39]. Plankton monitoring indicates the trophic status of the reservoir [20,40], but results have not been used to predict the evolution of fish stock. Despite the remaining terrestrial vegetation (mainly hard wood, the labile organic matter was decomposed in the first five years after impoundment) the reservoir is meso-oligotrophic, with a limited nutrient concentration, in particular in phosphorus. This evolution and apparent stabilization pattern was rapid when compared to that of other newly created tropical reservoirs [30]. Ten reservoir habitats were monitored to assess the relationships between fish catches and habitat characteristics [30]. Studies conclude that dense submerged forests are favorable to fish, with a number of species and of individuals at least twice higher than in other habitats. [24] determined that inundated habitat has a positive influence on the fish stock, as long as these habitats remain protected from fisheries activities. The reservoir fish stock also benefits from peripheral habitats such as upstream rivers and transition zones of special interest for conservation and resource protection [30].

\section{Fish Marketing}

Value adding includes all operations aimed at increasing the fresh fish marketability, such as processing, hygiene and quality control, packaging and labelling. In Lao PDR, processing fish mainly consists of drying fish for trade and making fermented fish sauce for selfconsumption [10]. Fish processing groups were created in 2015 at Nam Theun 2, with the aim to increase income from the fishery, and new processed products such as fish powder as protein supplement for children were tested [41]. However, many species have a higher value fresh than processed [22]. Around the reservoir, only $5-10 \%$ of the reported catch is processed [21]. Thus, fish processing is valued only when freshly caught fish cannot be sold, or when there is an oversupply. In a context of challenging fish trading, quality control in relation to hygiene, packaging and labeling standards may increase the value of fishery products and contribute to the economic sustainability of the fishery. However, no quality control was put in place at Nam Theun 2 - even though Village Fishing Groups recently focused on hygiene improvement with for example installation of water system at the fish processing group facilities. The monitoring of landing sites allowed quantifying the quantity, proportion and value of the yield sold, as well as the amount kept fresh or processed - even though that information was never published. Thus, between 2012 and 2016 the number of landing sites decreased by $40 \%$, but the mean catches and the mean value per landing more than doubled. In particular, the value of tilapia went down but that of wild species increased.

Yet, several aspects of the fishery remain undocumented, in particular factors driving fish sale, marketing strategies or trade channels. For instance, informal discussions with fishers indicate that less desirable species are sold at landing sites while high value ones are sold elsewhere; that traders often provide fishing gear to fishers in exchange of exclusivity, and that fish prices are fixed by traders and vary daily, depending on the overall catch of the day. Traders themselves seem to reflect a bottleneck at the level of final buyers, as there is not enough demand for all the fish harvested to be sold at a valuable price. Overall, beyond monitored but little popular landing sites, not much is known about fish sold within communities, at village markets and to wandering fish traders.

Infrastructure (landing sites, ice plants, market places, storage places and access roads) is essential for fish commercialization and subsequently for the sustainability of a fishery. The lack of investment into basic infrastructure and facilities for local fishing communities is considered as one of the reasons for the failure of fishing cooperatives at Nam Ngum reservoir [42]. Around Nam Theun 2 reservoir, 
each relocated hamlet had a fish landing site and market facilities constructed. Few years after the construction, activity varies between landing sites: four of them are operated yearlong while others are only functioning a few months per year [22]. The relative success of a landing site is mainly influenced by the location in the vicinity of productive fishing grounds. Of the ice plants constructed by NTPC around the reservoir, only one is still functional and operated by the fish processing group of the village. In all other communities, traders who use ice buy it from the district town. Because fish are usually sold a few hours after being caught, there is limited interest in preservation systems. Roads to bigger markets are good, and transport is not an issue for most northern villages and landing sites. The road network is more limited in southern villages but the fish is mainly transported by boat to northern landing sites [27]. The most significant constraint to transport reported is the price of fuel for boat engines. The marketability of a given fish species depends on its competitiveness in relation to other species, to similar species from closer origin or to aquaculture fish. In the case of Nam Theun 2, fish are subject to competition with fish from other inland fisheries (e.g., from Nam Ngum reservoir), with marine fish (e.g., horse mackerel) and with farmed fish (Phonvisay, 2013). The disappearance of high value capture species such as snakehead (e.g., Channa striata) and catfish (e.g., Hemibagrus spp.) in landings and the over-reliance on low value species, especially tilapia and hampala barb, limits the profitability of the fishery. Tilapia for instance ( $73 \%$ of catches), is massively farmed along the Mekong River, with a constantly low price. Another issue is the relatively large size of Nam Theun 2 reservoir tilapia, when buyers prefer smaller sizes. While several market options were initially considered, including export to Thailand and Vietnam [10], the current destinations remain within Laos, and nothing has been initiated nor conceptualized on this part of the fishery. Overall, trade networks and their contribution to the sustainability of the fishery have never been assessed; similarly, interventions in relation to final buyers and consumers have never been considered by any projects in Nam Theun 2 reservoir.

\section{Environment Policy in Relation to Fishing}

Administratively, fisheries are under the jurisdiction of the Province and District Agriculture and Forestry Offices (PAFO and DAFO) [43]. At the local level, fishers must be members of a Village Fishers Group (FVG). Each group elects members to join the Reservoir Fishers Association (RFA), whose representatives are part of the Reservoir Management Coordination Authority (RMCA). DAFO, Resettlement Management Units, the Nam Theun 2 Power Company and the Watershed Management and Protection Authority (WMPA) are also part of the RMCA, ensuring collegial decision-making about fisheries [43]. The Nam Teun 2 policies and operation are based on the Fisheries National law recently revised in 2016, with only a few exceptions concerning access, as detailed below.

The reservoir fishery was originally structured as a limited access fishery [10]: exclusive fishing rights have been granted for 20 years, until 2028, to residents of villages bordering the reservoir, resettled households and the second generation of resettled households [21]. Non-eligible fishers can buy a daily fishing license from either the
Village Fishing Groups or the Reservoir Fisheries Association, for a maximum catch of $5 \mathrm{~kg} /$ day. In practice, eligibility is flexible, with frequent migration, marriage/divorce and unclear village records of residents. It is also easy to bypass legal requirements for boat registration and membership to village fishing groups. Actually, the number of fishing licenses has steadily declined over the years. Developing the fishery was seen as a way to provide an alternative livelihood and improve income among villagers displaced by the dam project [10]; this is why fishery access rights are restricted to villagers around the reservoir. Since the creation of the reservoir, policies have been driven by the intention of sustaining or improving the income of fishers. Policy facilitation also included the involvement of Village Fishers Group and of a Reservoir Fishers Association in reservoir management. Acknowledging that only $9 \%$ of households originally owned a boat, between May-November 2008 the NTPC resettlement program provided the 1310 eligible households with 660 fishing boats, about 7 meters long, mostly shared between 2 households, as well as a set of fishing gear to each household. The budget also covered construction of Reservoir Fisheries Association offices, construction of ice plants, improvement of road access to landing sites, creation of and financial support to the Reservoir Fisheries Association, establishment of revolving funds and training in fishing and processing [44]. A Watershed Management Protected Area (WMPA) was established in 2008 and Village Protected Areas were established in 2013-2015. Fishing is banned in these protected areas [10] and at the connection between three north-east tributaries and the main reservoir (Figure 1).

Zoning was defined by the RMCA and enforcement was expected through peer control, i.e. by fishers themselves - although the risks of such approach were also foreseen [10]. To date, fishers keep operating in protected areas [21,45], fish protection areas remain to be established [26] and access restriction enforcement remains a challenge, linked initially to insufficient patrolling [26]. RMCA addressed in 2016-2018 by i) re-imposing manned checkpoints on the entry of selected conservation areas with high ecological significance and ii) improving the co-patrolling systems.

\section{Policy Environment in Relation to Trade}

In Nam Theun 2, the policies that facilitate or restrict fish commercialization consist of i) a legal framework (national, regional and communal legislations) and their local implementation; ii) local regulations (such as rules set up among Village Fisheries Groups), and iii) possible interference of local official or unofficial powers. The stability of regulations and to what extent they apply to all is another important parameter: in the case of the Nam Ngum reservoir fishery, the variable environment policy and changing practices of controlling fish market, fish prices and taxation system by the local provincial authorities are considered to have contributed to the failure of fishers' organization [42].

In order to operate around the reservoir, fish traders need to register and pay an annual license fee to District Trading Office. Fifteen to twenty fish traders were initially expected and fish trade was not meant to be regulated [10]. However, in 2017, fish trade became regulated and licenses became only accessible to villagers living around the reservoir, which resulted in their number dropping. 
Initially, facilitation by NTPC consisted of a credit scheme meant to help traders set up their business. That scheme covered main investment costs, e.g. access road improvement and provision of concrete slabs and shelter for fish trade. Assistance to the establishment of a fishing cooperative also involved in trading was also considered. In recent years, new initiatives were implemented to improve market accessibility to resettled communities with the aim of providing additional sources of incomes [26,41]. Rules and regulations around fish trade include ban to selling fish outside official landing sites and $7 \%$ taxes on transaction prices to the benefit of Village Fishing Groups and the Reservoir Fisheries Association. Actually, fishers and traders try to escape these taxes: the amount of fish sold at legal landing sites in 2016 is estimated at only $18-25 \%$ of the total amount sold, which compromises the funding and functioning of the above organizations $[22,26]$. A much more aggressive repression of illegal marketing was considered, but in practice, some Village Fishing Groups refrain from collecting taxes because it would reduce the chance of traders showing up. Since monitoring transactions also consumes up to $80 \%$ of the tax proceeds, it is questionable if full legal trade would benefit households more than the current situation. Overall, the trade channels are less studied or known than the biological resource [9]. In particular, the pros and cons of facilitation and constraint policy options have never been deeply discussed, and suggestions to liberalize trade, lift fishing licenses requirement and boat registration remain to be considered.

\section{Discussion}

The review of ten years of fisheries management at Nam Theun 2 illustrates how the multiple components of a fishery can be more or less covered by the promoters and managers of this fishery. What was not done and questions left unanswered are also aspects essential and are lacking for a comprehensive management for sustainability.

The connection between environmental studies and fishery management has mainly been through the identification of high ecological value areas to be protected. Beyond improving fish stock resilience, the social consequences of setting up conservation zones [46], and the differential impact on the various villages around the lake has not been considered. Yet experience from Marine Protected Areas in Southeast Asia shows that this management approach can produce "successful" biological outcomes but less successful social outcomes [47]; this calls for use of criteria measuring both biological and social success. Fishing effort, well monitored and documented, focused on registered boats, but field data indicates that close to $60 \%$ of the fishing effort originates from unregistered boats - which also affects knowledge of the fish supply. Regulation of the fishing effort remains a weak point. Annual harvest monitoring underline the evolution of the reservoir towards an oligo-mesotrophic status, with a naturally limited fish production. The social component of the fishery is well documented, although not published. The focus has been on socio-economics (income, fishing effort, etc.), in relation to the resettlement program of the company. However, there have been no studies about aspirations or constraints of the fishing community. Socio-cultural drivers of fishers' involvement or behavior are an important component of the sustainability of a fishery [48]. In the case of Nam Theun 2 reservoir, questioning the functioning of fisher associations could have flagged representativeness or ownership issues [49]. Researching why fishers do not comply with regulations (respective role of deterrence, moral support and authority [50,51] as well as cultural and psychological dimensions (e.g., degree of concern about management for sustainability in a context of severe environmental modification, skepticism about benefits to be expected from access restriction in protected areas, etc. [52] could have suggested management options closely matching fishers' perspectives. More generally, understanding better how changes in a fishery system influence social networks, community cohesion, culture and local institutions [53] could have helped better address villagers' adaptation challenges. Consumption of fish by fishing families ("self-consumption") has been a strong argument in favor of fishery development and nutritional improvement. This theme was covered in several technical reports, but the project has not produced any specific study on this point.

Fish prices and the value of the fish officially traded have received specific attention. However, a detailed study of the dominant trading outside official channels, of the demand variability, of trade drivers or of arrangement between fishers and traders remains to be undertaken. More generally, the role of middlemen is usually overlooked, yet experience from marine fisheries shows that credit arrangements, reciprocal agreements and financial guarantees also have stabilizing social effects and contribute to sustainability [54,55]. Infrastructure development received special attention (investment, documentation). However, it seems that economic factors limit the demand for processing, and this aspect has not been studied. Similarly, the demand for quality control, ice facilities and transport improvement has been limited. Activities have focused on the construction of landing sites and market places. Since the fishing pressure can be predominantly driven by cities and market access [56], it is important to understand social-ecological linkages in the fishery. Importantly, the demand from buyers has not been subject to any study nor strategic analysis. However, serious constraints apply at this level, in terms of fish species preferences, competitive price per species or competition with other sources of fish including aquaculture and imported marine fish. All these constraints have had a substantial influence on the success and sustainability of the fishery. On the policy side, the regulatory environment in relation to fishing is substantial but sparsely documented, with emphasis in facilitation initiatives (provision of 600 boats, etc.) and access restrictions. However, an analysis of the pros and cons of the various regulatory measures, in a context where enforcement is recognized as a major challenge, remains to be done. The same comments apply to the regulatory environment in relation to fish trade, and the latter is hardly documented. The efficiency of the current policy framework remains disputed, and simplification has been recommended by several sources: the current policy complexity and its implementation challenges do not seem to guarantee the sustainability of the reservoir fishery. The above elements are summarized in Figure 3.

[57] underline the need to define, for a fishery, quantitative objectives guiding adaptive management (harvest, income, nutrition status or employment of targeted beneficiaries) - which was not developed at Nam Theun 2. [58] note that management objectives 


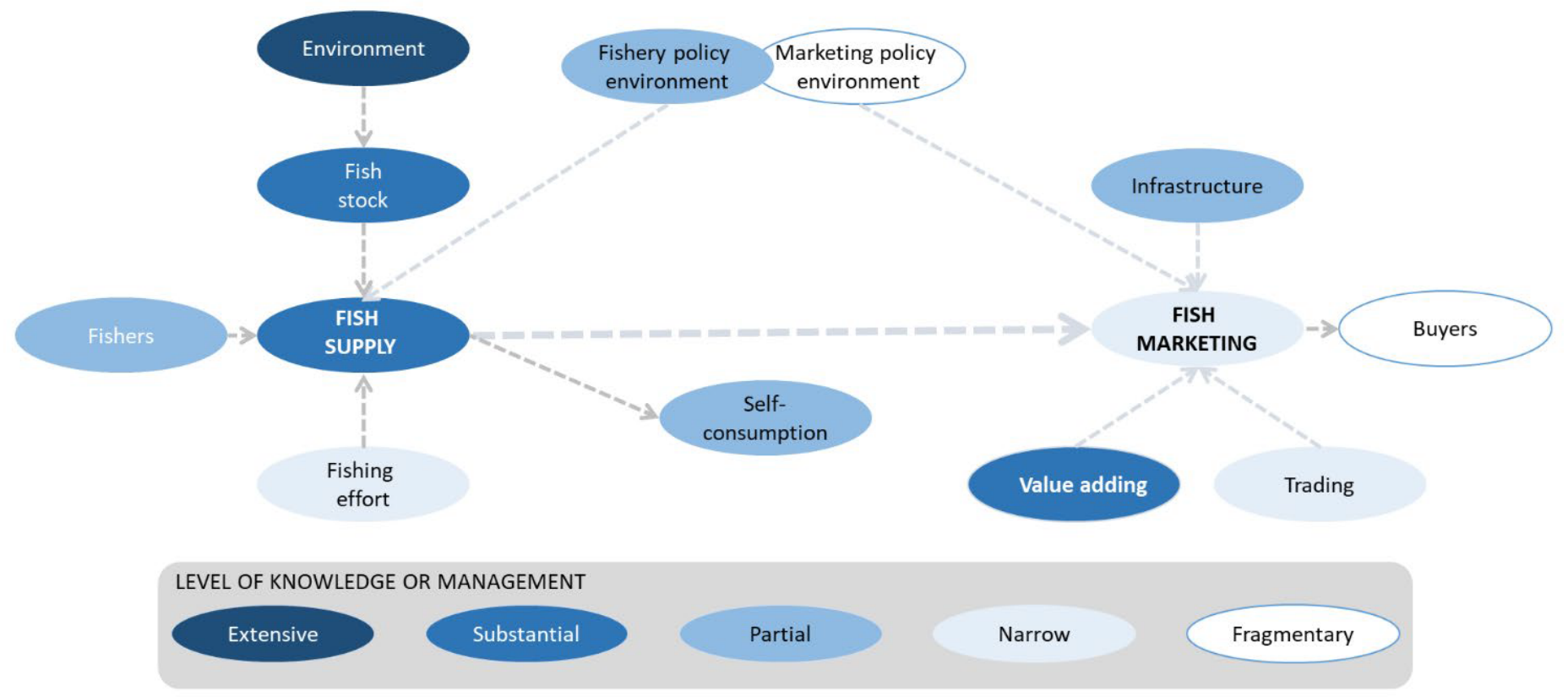

Figure 3: Mapping of the knowledge base about the various components of the Nam Theun 2 reservoir fishery
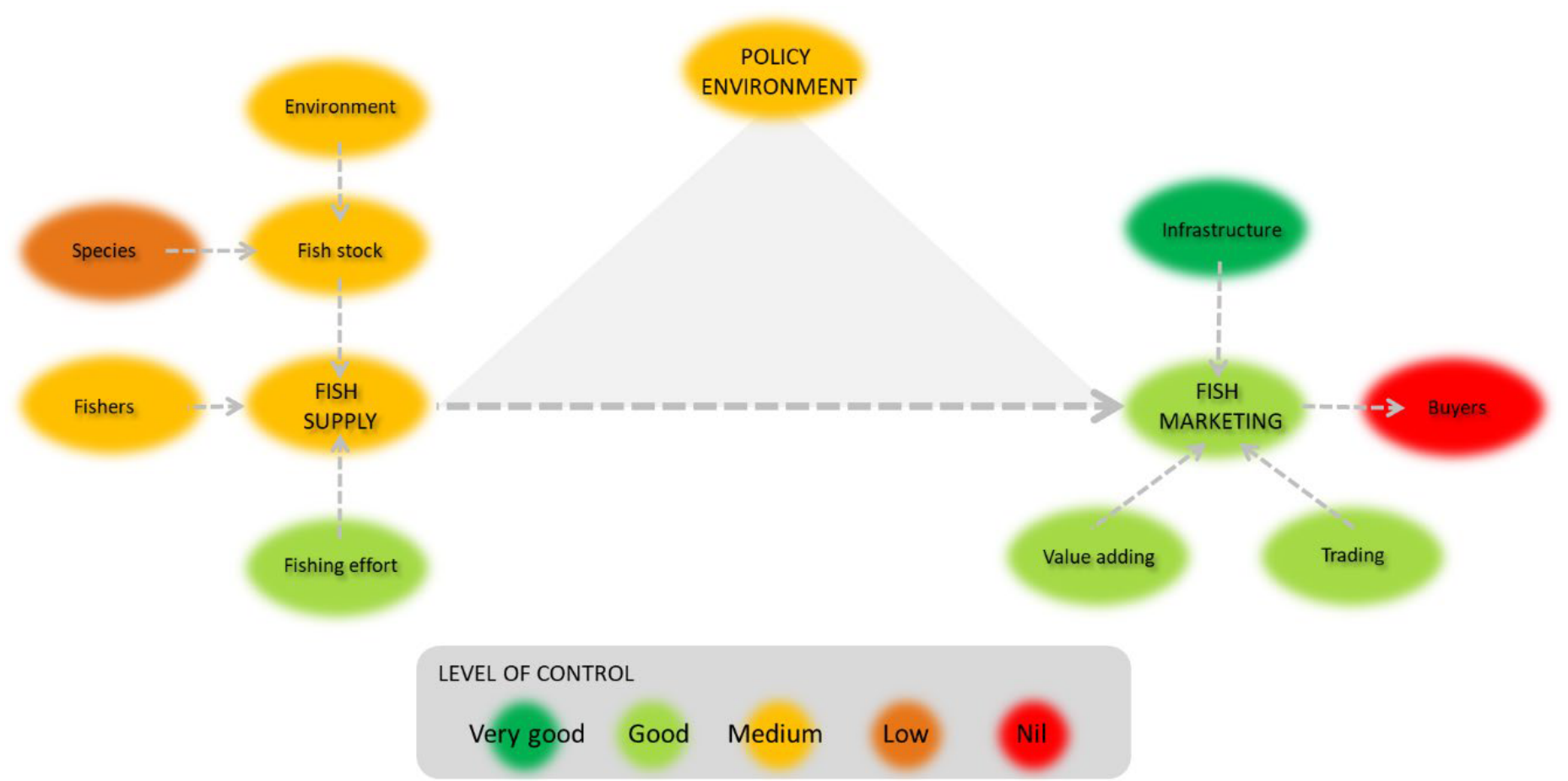

Figure 4: Degree of possible influence of fishery managers over the Nam Theun 2 reservoir fishery system

are ultimately political, and acknowledge that management bodies generally do not establish clear objectives. However, the need to set biological and social objectives to management decisions is widely recognized [59,60]. The challenge in setting measurable and realistic objectives is acknowledged, but the lack of clear biological, social or economic targets is a major risk in developing a fishery. Overall, sustainable management does not require the same high degree of knowledge about each component of the system, the information need being proportional to the degree of decision -making and control over a given component. A map of the extent of possible influence of the Nam Theun 2 fishery managers is proposed below (Figure 4). Nuances reflect the degree of freedom of the fishery actors and the technical feasibility of interventions in a given component.

A comparison of what is known or done (Figure 3) with what can be influenced (Figure 4) highlights the strong points of a fishery (here good knowledge of the environment and of the resource, and investment in infrastructure) and the less managed or manageable 
ones (here actors and their drivers, marketing and the market demand). For the latter, additional knowledge might not immediately translate into influence over that component. These aspects are part of the challenges of small-scale fisheries governance and open to a contribution to the discussion on governability, i.e. the degree to which a fishery system is deemed governable [61-63].

\section{References}

1. Zarfl C, Lumsdon AE, Berlekamp J, Tydecks L, Tockner K (2015) A global boom in hydropower dam construction. Aquatic Science 77: 161-170.

2. Ziv G, Baran E, Nam S, Rodríguez-Iturbe I, Levin SA (2012) Trading-off fish biodiversity, food security, and hydropower in the Mekong River Basin. PNAS, 109: 5609-5614.

3. Ainsworth R, Cowx IG, Funge-Smith SJ (2021) A review of major river basins and large lakes relevant to inland fisheries. FAO Fisheries and Aquaculture Circular No. 1170. Rome, FAO. Rome, FAO.

4. Clay CH (1984) New reservoirs in Africa, 1980-2000. Ontario, Canada, CIFA Occasional Paper 23.

5. Sugunan VV (1995) Reservoir fisheries of India (FAO Fisheries Technical Paper No. 345). Rome, Italy, Food and Agriculture Organization of the United Nations, 423.

6. Petrere M (1996) Fisheries in large tropical reservoirs in South America. Lakes and Reservoirs: Research and Management 2: 111-133.

7. De Silva SS (2001) Reservoir and culture-based fisheries: biology and management. Proceedings of an International Workshop held. Bangkok, Thailand, ACIAR Proceedings No. 98: 384.

8. Wle Greater Mekong (2018) Dams in the Mekong River Basin, Laos: commissioned, under construction and planned dams in September 2017.

9. Phonvisay S (2013) An introduction to the fisheries of Lao PDR. Report Mekong Development Series No. 6. Phnom Penh, Cambodia, Mekong River Commission 56.

10. NTPC (2005) Nam Theun 2 hydroelectric project, Social development plan. Vientiane, Lao PDR, Nam Theun 2 Power Company 25.

11. Arlinghaus R, Lorenzen K, Johnson BM, Cooke SJ, Cowx IG (2016) Management of freshwater fisheries: addressing habitat, people and fishes. In: J.F. Craig (Eds.), Freshwater Fisheries Ecology 557-579. Chichester, UK, Wiley Blackwell 920.

12. Welcomme RL (2016) Fisheries governance and management. In: J.F. Craig (Eds.), Freshwater fisheries ecology 467-482. Chichester, UK, Wiley Blackwell, 920.

13. Bush SR, Marschke M (2017) Social and political ecology of fisheries and aquaculture in Southeast Asia. In: P. Hirsch (Eds.), Routledge handbook of environment in Southeast Asia 224-238. London, UK, Routeledge Handbook, 522.

14. Welcomme RL (2001) Inland Fisheries: Ecology and Management. Blackwell Science, Oxford.

15. Wiber M, Berkes F, Charles A, Kearney J (2004) Participatory research supporting community-based fishery management. Marine Policy 28: 459-468.

16. Pomeroy RS, Andrew N (2011) Small-scale fisheries management: frameworks and approaches for the developing world. Oxfordshire, UK, CAB International 260.

17. Townsley P (1993) A manual on rapid appraisal methods for coastal communities. Madras, India, Bay of Bengal Programme.

18. Pido MD, Pomeroy RS, Carlos MB, Garces LR (1996) A handbook for rapid appraisal of fisheries management systems. Manila, Philippines, International Centre for Living Aquatic Resources Management 85.

19. Hortle KG (2007) Consumption and the yield of fish and other aquatic animals from the Lower Mekong Basin (MRC Technical Paper No. 16). Vientiane, Lao PDR, Mekong River Commission, 87.

20. Descloux S, Cottet M (2016) Five years of monitoring of zooplankton community dynamics in a newly impounded sub-tropical reservoir in Southeast Asia (Nam Theun 2, Lao PDR). Hydroécologie Appliquée 19: 197-216.

21. Cottet M, Visser TA (2017) Fish catch and fishing practices in the Nam Theun 2 Reservoir and watershed (Lao PDR). Lakes and Reservoirs: Research and Management 22: $334-348$.
22. Visser T (2016) Fisheries status in Nakai reservoir. Annual report 2016. Vientiane, Lao PDR, Nam Theun 2 Power Company, 48.

23. Tessier A, Cottet M, Kue K, Chanudet V, Descloux S, et al. (2020) Low input of offshore areas to fisheries in a large tropical reservoir in Lao PDR. Limnology 21: 73-86.

24. Tessier A, Guillard J (2018) Fish population of Nam Theun 2: stock, fisheries and life history traits of the main species. Thonon-les-Bains, France, UMR CARRTEL, Institut National de la Recherche Agronomique 146.

25. Visser T (2018) Fisheries status in Nakai reservoir. Final report. Vientiane, Lao PDR, Nam Theun 2 Power Company.

26. Mcdowell DK, Mann E, Talbo LM (2016) Lao People’s Democratic Republic Nam Theun 2 multipurpose project: twenty-fifth report of the international environmental and social panel of experts (Report No. 25). Vientiane, Lao PDR, World Bank Group 59

27. Ando S, Sakamoto M, Souksavath B (2017) Who is responsible for decision-making in participatory development? - Lessons learned from the social reconstruction plan for the Nam Theun 2 dam project. Journal of Asian Development 3: 146-161.

28. World Bank and Asian Development Bank (2013) Nam Theun 2 annual update: project progress during 2013. Vientiane, Lao PDR, World Bank Group and Asian Development Bank.

29. Phonesavath K (2017) Evaluation of community engagement in Nam Theun 2 hydropower project in Lao People's Democratic Republic. Master Thesis of Water Resource Management). University of Canterbury, Canterbury, New Zealand.

30. Cottet M, Descloux S, Guédant P, Cerdan P, Vigouroux R (2016) Fish population dynamic in the newly impounded Nam Theun 2 Reservoir (Lao PDR). Hydroécologie Appliquée 19: 321-355.

31. Tessier A, Guillard J, Chanudet V, Cottet M (2017) Length-weight relationships of eight Asian freshwater fish species in Nam Theun 2 Reservoir (Laos PDR). Journal of Applied Ichthyology 33: 658-660.

32. Tessier A, Beaune D, Guillard J, Kue K, Cottet M, et al. (2019a) Life history traits and exploitation of Hampala barb (Hampala macrolepidota -Cyprinidae) in a subtropical reservoir (Lao PDR). Cybium 43: 351-365.

33. Tessier A, Blin C, Cottet M, Kue K, Panfili J, et al. (2019b) Life history traits of the exploited Nile Tilapia (Oreochromis niloticus - Cichlidae) in a subtropical reservoir (Lao PDR). Cybium 43: 71-82.

34. Costa-Pierce BA (1997) From Farmers to Fishers: Developing Reservoir Aquaculture for People Displaced by Dams. Washington, USA, World Bank Publications, 56.

35. Kottelat M (1998) Fishes of the Nam Theun and Xe Bangfai basins, Laos, with diagnoses of twenty-two new species (Teleostei: Cyprinidae Balitoridae, Cobitidae, Coiidae and Odontobutidae). Ichthyological Exploration of Freshwater 9: 1-128.

36. Kottelat M (2016) The fishes of the Nam Theun and Xe Bangfai drainages, Laos. Hydroécologie Appliquée 19: 271-320.

37. Chanudet V, Fabre V, Van Der Kaaij T (2012) Application of a three-dimensional hydrodynamic model to the Nam Theun 2 Reservoir (Lao PDR). Journal of Great Lakes Research 38: 260-269.

38. Chanudet V, Guédant P, Rode W, Godon A, Guérin F, et al. (2016) Evolution of the physico-chemical water quality in the Nam Theun 2 Reservoir and downstream rivers for the first 5 years after impoundment. Hydroécologie Appliquée, 19: 27-61.

39. Chanudet V, Smits J, Van Beek J, Boderie P, Guérin F, et al. (2016) Hydrodynamic and water quality 3D modelling of the Nam Theun 2 Reservoir (Lao PDR): predictions and results of scenarios related to reservoir management, hydrometeorology and nutrient input. Hydroécologie Appliquée 19: 87-118.

40. Martinet J, Descloux S, Guedant P, Rimet F (2014) Phytoplankton functional groups for ecological assessment in young sub-tropical reservoirs: case study of the NamTheun 2 Reservoir, Laos, South-East Asia. Journal of Limnology 73: 536-550.

41. NTPC (2017) Environment and Social Monitoring Report: Annual Progress Report January-December 2017. Vientiane, Loa PDR, Nam Theun 2 Power Company 417.

42. Sommano P (2015) Review of fisheries management and development in large hydropower reservoirs of Lao PDR (case study of Nam Ngum 1). Secondary Review of fisheries management and development in large hydropower reservoirs of Lao PDR (case study of Nam Ngum 1). Vientiane, Lao PDR 20. 
43. Visser $\mathrm{T}$ (2013) Review of regulatory framework for developing fisheries management plan in Nakai Reservoir. Vientiane, Lao PDR, Nam Theun 2 Power Company, 50.

44. Visser T, Buranakul N (2012) Nakai reservoir fisheries status report. Vientiane, Lao PDR, Nam Theun 2 Power Company, 54.

45. Visser T (2015) Fisheries status in Nakai reservoir. Annual report 2014. Vientiane, Lao PDR, Nam Theun 2 Power Company, 36.

46. Stevenson TC, Tissot BN, Walsh WJ (2013) Socioeconomic consequences of fishing displacement from marine protected areas in Hawaii. Biological Conservation 160: 50-58.

47. Christie P (2004) Marine protected areas as biological successes and social failures in Southeast Asia. In J.B. Shipley (Eds.), American Fisheries Society Symposium 42: 155-164. Brasilia, Brazil, American Fisheries Society 301.

48. Barclay K, Voyer M, Mazur N, Payne AM, Mauli S, et al. (2017) The importance of qualitative social research for effective fisheries management. Fisheries Research 186: 426-438.

49. Rangel M, Pita C, Oliveira MM, Guimaraes MH, Rainha R, et al. (2019) Do fisher associations really represent their members' needs and opinions? Marine Policy 101: 276-284.

50. Gezelius SS, Hauck M (2011) Toward a theory of compliance in state-regulated livelihoods: a comparative study of compliance motivations in developed and developing world fisheries. Law and Society Review 45: 435-470.

51. Tran TPH, Van Dijk H (2013) Fishery livelihoods and (non-)compliance with fishery regulations-a case study in Ca Mau Province, Mekong Delta, Viet Nam. Marine Policy 38: 417-427.

52. Carr LM, Heyman WD (2012) It's about seeing what's actually out there": Quantifying fishers' ecological knowledge and biases in a small-scale commercial fishery as a path toward co-management. Ocean and Coastal Management 69: 118-132.

53. Katikiro R, Deepananda KHMA, Macusi E (2015) Interplay between perceived changes in fishery and social structures in Tanzanian coastal fishing communities. Fisheries Research 164: 249-253.
54. Crona B, Nyström M, Folke C, Jiddawi N (2010) Middlemen, a critical socialecological link in coastal communities of Kenya and Zanzibar. Marine Policy 34: 761-771.

55. Ferrol-Schulte D, Ferse SCA, Glaser M (2014) Patron-client relationships, livelihoods and natural resource management in tropical coastal communities. Ocean and Coastal Management 100: 63-73.

56. Phonvisay A, Bualaphanh V, Sichanh S, Singhanouvong D, Hortle KG (2006) Monitoring of fish markets in Vientiane and Luang Prabang Province, Lao PDR, using logbooks. In T.J. Burnhill TJ Warren (Eds.), Proceedings of the 7th Technical Symposium on Mekong Fisheries 47-60. Ubon Ratchathani, Thailand, Mekong River Commission 324.

57. Cochrane KL, Garcia SM (2009) A fishery manager's guidebook. Chichester, UK, Food \& Agriculture Organization of the United Nations and Wiley Blackwell 536.

58. Marasco RJ, Miller ML (1989) The role of objectives in fisheries management. In: W.S. Wooster (Eds.), Fishery science and management: objectives and limitations 171-186. Seattle, USA, Springer, 338.

59. Mardle S, Pascoe S, Boncoeur J, Le Gallic B, García-Hoyo JJ, et al. (2002) Objectives of fisheries management: case studies from the UK, France, Spain and Denmark. Marine Policy 26: 415-428.

60. Brooks K, Schirmer J, Pascoe S, Triantafillos L, Jebreen E, et al. (2015) Selecting and assessing social objectives for Australian fisheries management. Marine Policy 53: 111-122.

61. Jentoft S, Chuenpagdee R (2015) Interactive governance for small-scale fisheries: global reflections. Switzerland, Springer.

62. Song AM, Bower SD, Onyango P, Cooke SJ, Akintola SL, et al. (2018) Intersectorality in the governance of inland fisheries. Ecology and Society 23: 2-17.

63. Descloux S, Guedant P, Phommachanh D, Luthi R (2016) Main features of the Nam Theun 2 hydroelectric project (Lao PDR) and the associated environmental monitoring programmes. Hydroécologie Appliquée 19: 5-25.

\section{Citation:}

Baran E, Visser T, Cottet M, Tessier A, Guerin E, et al. (2021) A Case Study of Fisheries Governance and Management in a Reservoir of Lao PDR: Perspectives for Improvement. Aquac Fish Stud Volume 3(3): 1-9. 